\title{
Sustainability in engineering programs in a Portuguese Public University
}

\author{
Ciliana Regina Colombo ${ }^{\mathrm{a} *}$, Anabela Carvalho Alves ${ }^{\mathrm{b} * *}$ \\ aUniversidade Federal do Rio Grande do Norte, Natal, RN, Brasil

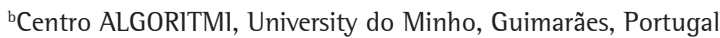 \\ *cilianacolombo@gmail.com, **anabela@dps.uminho.pt
}

\begin{abstract}
Rethink the interventions, human practices and their effects on the natural environment, for the preservation of life and biodiversity, threatened by the capitalist model of production, consumption and disposal, becomes each day more indispensable. The role of universities as knowledge building space is fundamental for the insertion of the environmental approach (greening) in its various fronts (education, research, extension, and management). Following the line of several types of researches about the subject, this paper aims to identify if and how the issue of sustainability (e.g. through Project-Based learning use) is taught in the various engineering programs of a Portuguese Public University. This study was carried out by a documental research based on the programs' curricula published in the official website of the university. The engineering programs selected included integrated master, master (second cycle) and doctorate (third cycle). In this study, it was identified programs that are more focused on sustainability concepts than others, so the programs were classified in three categories: strongest, medium and weakest focus.
\end{abstract}

Keywords

Engineering education. Sustainability. Environment. Greening of engineering programs and courses.

How to cite this article: Colombo, C. R., \& Alves, A. C. (2017). Sustainability in engineering programs in a Portuguese Public University. Production, 27(spe), e20162214. http://dx.doi.org/10.1590/0103-6513.221416

\section{Introduction}

Sustainability is on the agenda, being one of the keywords in the spotlight. As a curiosity, a google search with this keyword produced $164,000,000$ results in just 0.48 seconds, at the time of this paper writing. Teaching and engaging students in this issue are of prime importance as noticed by United Nations: "Education for all has always been an integral part of the sustainable development agenda" (United Nations, 2016a). This same organization launched a decade dedicated to Education for Sustainable Development (DESD) that was the decade of 2005-2014 (United Nations Educational, Scientific and Cultural Organization, 2005). This aimed the integration of the principles and practices of sustainable development into all aspects of education and learning, the encouragement to changes in knowledge, values, and attitudes with the vision of enabling a more sustainable and just society for all. The collaboration of a vast number of stakeholders - across the Member States, UN agencies, the education sector, the private sector and civil society - was demanded to work in partnership to reorient education systems towards sustainable development. The report "Shaping the future we want" wrap-up the conclusions of DESD (United Nations Educational, Scientific and Cultural Organization, 2014).

As a follow-up of DESD, UNESCO launched the Global Action Program (GAP) on ESD. The overall goal of the GAP is to generate and scale up actions in all levels and areas of education and learning to accelerate progress towards sustainable development. The GAP is twofold: to reorient and to strength education in all agendas, programs and activities that promote sustainable development in order to everyone (educators, youth and local communities) to have the opportunity to acquire the knowledge, skills, values and attitudes that empower them to contribute to sustainable development and make a difference (United Nations, 2013). 
In the context of GAP, a new initiative was created by the time of United Nations Conference on Sustainable Development, Rio+20. This initiative was called Higher Education Sustainability Initiative (HESI). It aims to stimulate commitments from Higher Education Institutions (HEl) to teach and encourage research on sustainable development, greening campuses and support local sustainability efforts. Almost 300 universities worldwide, joined the HESl, being compromised to: 1) Teach sustainable development across all disciplines of study, 2) Encourage research and dissemination of sustainable development knowledge, 3) Green campuses and support local sustainability efforts, and 4) Engage and share information with international networks (United Nations, 2016b).

More HEl must join this effort and a good beginning could be starting by diagnose the programs existent in the HEl by, for example, developing benchmarking studies (Allen et al., 2008) or reports (Hansen et al., 2014a; Ruscheinsky et al., 2014) that clarifies the situation and provides good examples for others to follow (Hansen et al., 2014b). This gave the motte for this paper that it has as the main goal to identify in a Portuguese Public university engineering programs and courses the issue of sustainability. This research extends the study of Colombo \& Alves (2016) by including the Master degrees (second cycle) and Doctoral programs (third cycle). To develop this study, the papers 'authors used the existent information (curricula) provided on the university official website by identifying the word sustainability or related (e.g. environment, green,...) in the programs and courses. The categories used in the first study (Strongest and Weakest) were also extended to include a Medium category in the Masters and Doctorates. These were slightly different in their organization because they add more optional courses that students are not compelled to have. Results are very disappointing because just a small percentage of programs and courses includes sustainability issues. Particular attention was also given to the learning methodology used in the course to discern the "how" sustainability is taught.

This paper is organized in the five sections. This first section introduces the theme relevance and the objectives of the paper. The second section introduces a brief literature review. The research methodology used is introduced in the third section. Section four introduces the study context and present the core of the paper exposing the degrees, programs and courses that were identified by having contents sustainability issues. The last section presents some final remarks.

\section{Brief literature review}

The need to integrate sustainability in education was largely recommended during the decade of Education for Sustainable Development (DESD) (United Nations Educational, Scientific and Cultural Organization, 2005). Recognizing the importance to continue this effort, the same organization launched the Global Action Program (GAP), already referred (United Nations, 2013). In the last report from DESD (United Nations Educational, Scientific and Cultural Organization, 2014) the need to mentor and evaluate the efforts that seek to reorient education systems was identified. In the same report, this was considered one of the most persistent challenges still to be addressed. Some studies and publications have been published with this concern (Allen et al., 2008; Bernaldo et al., 2016; Cotton et al., 2009; Hansen et al., 2014a; Wigmore \& Ruiz, 2010).

Other actions suggested on UNESCO (United Nations Educational, Scientific and Cultural Organization, 2014) report are related to: 1) Expand and promote a leadership development for senior university executives and governors (including coaching, peer learning, action learning and mentoring support; 2) Endeavor new approaches to curriculum reform (including capacity-building for academic staff); 3) Move sustainable development beyond a specialist 'career' focus to a learning outcome and lifelong orientation across all fields of study; 4) Track systematically sustainability-related research, noting in particular whether and how it is influencing change in policy and practice beyond the institutions; 5) Strength greening campus operations through mechanisms to share tools and approaches, including carbon footprint reductions; and, finally, 6) Scale up collaboration and partnerships between university researchers and community stakeholders as mechanisms to deepen learning, strengthen the knowledge base on local social, environmental and economic issues and contribute to solutions for local-level sustainability.

Before promoting these actions, many challenges must be overcome, also referred in UNESCO (United Nations Educational, Scientific and Cultural Organization, 2014) as: 1) translation of commitments into implementation requires coordinated change at multiple levels - in governance, planning, academic programs, facility management and financial systems; 2) deeper innovation in staff development and across institutions is necessary to transform curricula and pedagogy and 3) disciplinary boundaries continue to be barriers to the exploration of complex issues, and to the preparation of learners with the capacity to address complexity.

These challenges are, many times, difficult to overcome. This has been testified by the authors of this paper in their experience with Project-Based learning (PBL) implementation in developing projects akin to whole-systems sustainability solutions (product and production system design, green and eco-efficiency solutions 
of the supply chain (Alves et al., 2016). Fortunately, as in this example illustrated in this publication, there are many $\mathrm{HEl}$ worldwide that are promoting (or are trying to promote) good examples of programs and initiatives to greening the campus of universities and educate for sustainable development, namely: (Daneikina et al., 2016; Hansen et al., 2014b; Holgaard et al., 2016; Holmberg et al., 2008; Junyent \& Ciurana, 2008; Mello et al., 2016; Sammalisto \& Lindhqvist, 2008).

A key sustainability player on the DESD are the students. These should be engaged to be pro-active and push the shift of a new thinking and practice in HEl. Students should not be any more spectators but sustainability key actors and change agents in the HEl. But how to involve them if learning methodologies and contents in the programs remain unchanged? The easier integration way to integrate sustainability is introducing a course or more about this issue and this could result better when more courses are integrated however this is not the most efficient way. According to some studies and proposals by DESD, the sustainability issue is an interdisciplinary theme and to be effectively learned by the students should be worked in a much more involved way, i.e., must be worked in a transversal way in activities that involved diversified courses or knowledge learned in them.

PBL has been revealed to be an efficient methodology to work sustainability in engineering programs, being a model already implemented in various universities, namely Aalborg University, Denmark (Guerra et al., 2013; Dahms et al., 2013; Hansen et al., 2014a) and in the university of this study (Colombo et al., 2014; Colombo et al., 2015a). According UNESCO (United Nations Educational, Scientific and Cultural Organization, 2014) report, a significant driver for changes in curriculum and teaching practice is the increase of student demand for a sustainability centered education that should be monitored more closely and PBL could allow this.

\section{Research methodology}

The research methodology used was a documental research, mainly, based on the information available on the official website of the studied university. The research questions that guided this study were:

1. What are the engineering programs that includes sustainability concepts in the curricula?

2. In the programs identified, how many and what courses includes sustainability concepts?

3. How are the sustainability concepts taught to the students (i.e. the teaching/learning methodologies and methods used)?

In order to compile the data collected from the websites and answer the research questions, an excel file was built to register the Integrated Master degrees, Master and Doctoral programs. Integrated Master is the designation adopted by many Portuguese universities for some programs after Bologna Process (European Association of Institutions in Higher Education, 1999; European Commission \& Education, Audiovisual and Culture Executive Agency, 2010). An Integrated Master, normally, includes five years of study (three that corresponds to a first cycle and two more years that corresponds to the second cycle of studies) in a total of 10 semesters. Each program has, normally, 300 European Credits Transfer System (ECTS) (30 ECTS by semester). ECTS is an instrument adopted by Europe after Bologna process to facilitate the comparability of degrees in Higher Education in the European space (46 countries). One ECTS represents, normally, 25-30 hours of student work.

The Master programs (MSc) corresponds to a second cycle of studies and, normally, includes four semesters and 120 ECTS. The Doctoral programs (PhD) includes, with some exceptions, 240 ECTS. The PhD incorporates a year with courses and two years to develop the thesis, so it is short duration program and much focused in a specific area.

The study plan of each Master Integrated degree was analyzed and the courses, compulsory and optative, with a title related to sustainability, were counted and registered in the excel file referred above. After identified the courses, the paper' authors read, interpreted and analyzed the objectives of education, key learning outcomes and program summary. For each was also registered the ECTS number and the teaching and assessment methods.

Also, it was registered the courses of each Master and $\mathrm{PhD}$, quantifying the number of courses that are related to sustainability. This allowed the authors to define criteria in order to identify the programs more or less focused on integrating sustainability in the courses. In a first paper (Colombo \& Alves, 2016), it was decided to classify in two groups the engineering programs attending to the number of courses related to sustainability and the corresponding number of ECTS: 1) Strongest: programs very akin with inclusion of sustainability in many courses; 2) Weakest: programs with one or none courses with this topic.

With the extended study to master degree and doctorate programs this classification was also extended to include one more category: medium. This was necessary because there are programs with a number of 
"Sustainability forms part of what we do" of the study of Hansen et al. (2014b).

Thus, in this study the categories considered were:

- Strongest focus - programs that have more than three courses related to sustainability. According to (Hansen et al., 2014b) is the category "Sustainability is everything we do!" that means programs very akin with inclusion of sustainability in many courses.

- Medium focus - programs that have up to three courses related with sustainability. This corresponds to the category "Sustainability forms part of the what we do" of Hansen et al. (2014b) that means sustainability is not at all visible in the program curricular and yet there are elements of sustainability in some of these programs.

- Weakest focus - programs without courses with sustainability topics.

It is important to consider that the study from Hansen et al. (2014a) was a qualitative research, while this study is predominately quantitative and deeper considerations related to the sustainability integration could not be done. This study is limited by the contents on the official website that normally is not detailed enough. Another research method such as interviews should be used, to deep this study, to better understand if and how sustainability concepts are worked in the course. As the study of Dahms et al. (2013) demonstrated, results of a documentary analysis could be very different from the interviews results.

\section{Sustainability contents in engineering programs and courses}

This section presents the university context where this study was based. After this, the programs and their classification are presented and a proper discussion is followed.

\subsection{Study context}

This study was developed in a Portuguese Public University located in the North region of Portugal. It has about 20,000 students, of whom approximately 50\% are MSc and PhD students. The University is on the top of the Portuguese Universities listed in the Times Higher Education ranking from The 100 under 50 (2013, 2014). This University has many projects with the goal of promoting sustainability in the campi and in the around community such as the compromise to launch sustainability reports yearly, an Agency for Energy and Environment (AUMEA) and a Landscape Laboratory. Additionally, this University has many research units concerned with the sustainability, being the most recent, the Institute of Science and Innovation for Bio-Sustainability (IB-S).

This University produces a sustainability report since 2010 following the Global Reporting Initiative (GRI) guidelines. These guidelines defined three dimensions for the performance indicators: environmental, social and economic that this university measure. Additionally, the university introduced a fourth dimension: cultural due to the strong emphasis in a cultural activity (Ramísio, 2015). This University as an institution is concerned with sustainability and as a Higher Education Institution has also been concerned that their curricula promote opportunities for their students to learn, to research, to innovate and to reflect in sustainability contents and main issues.

This university has eight Schools and three Institutes, specified below:

1. School of Architecture

2. School of Sciences

3. School of Health sciences

4. School of Law

5. School of Economics and Management

6. School of Engineering

7. School of Psychology

8. School of Nursing

9. Institute of Social Sciences 


\section{Institute of Education}

\section{Institute of Arts and Human Sciences}

The School of Engineering programs are the selected sample for this study and, in the period 2016/2017 includes 15 Integrated Master Degrees (IMSc), 27 Master degrees (MSc) and 24 Doctoral Programs (PhD). Table 1 presents a summary for the degrees of School of Engineering.

The English page of the university website was consulted to obtain the information. However, some courses were not in English, just in Portuguese, so the paper authors hope that the translation made was the one expected.

The following sections present these degrees from the lowest to the higher level. Each section is divided in a main section and three subsections. Each main section presents a table that presents the classification of the degrees by the three categories referred in the research methodology (to answer the second research question). In the main section is also provided a summary of the teaching/learning methodology revealed in the websites of each course. Each exception is described in the program/course respective (to answer the third research question) in each subsection.

\subsection{Integrated Master degrees: sustainability focus}

This section presents the 15 Integrated Master's degree (IMSc) identified in Table 1. The Table 2 presents the results of the collected IMSc, and the number of courses with a name related to sustainability thematic. These programs were ordered by the number of courses related with sustainability and the corresponding number of ECTS to facilitate their classification in the discussion section.

About the approach and teaching/learning methodologies to work sustainability or something related, there was no direct information in the presentation of the courses. The description of some of the courses talks about the importance of the integration between theory and practice and also the development of the critical and creative spirit of the students, but nothing is specified about the methodology used for this. Without further details, it is mentioned on the websites of each course that this is based on work groups and/or projects, but

Table 1. Summary of the degrees of School of Engineering.

\begin{tabular}{|c|c|c|c|}
\hline Type of degree & IMSc & MSc & $\mathrm{PhD}$ \\
\hline Programs & 15 & 27 & 23 \\
\hline Years & 5 & 2 & 3 \\
\hline Semesters & 10 & 4 & 6 \\
\hline ECTS (average) & 300 & 120 or 90 or 60 & 240 or 180 or 210 \\
\hline Total of compulsory courses (average) & 45 & 11 & 7 \\
\hline Total of offered courses* & 672 & 296 & 173 \\
\hline
\end{tabular}

*1t includes compulsory and optional.

Table 2. Number of courses and ECTS related with sustainability in IMSc degrees and their category.

\begin{tabular}{|c|c|c|c|c|}
\hline & Master lntegrated in: & $\begin{array}{c}\text { Courses related } \\
\text { with sustainability: }\end{array}$ & Number of ECTS: & Category \\
\hline 1 & Civil Engineering & 18 & 90 & \multirow{3}{*}{ Strongest } \\
\hline 2 & Biological Engineering & 12 & 65 & \\
\hline 3 & Materials Engineering & 5 & 25 & \\
\hline 4 & Polymer Engineering & 2 & 10 & \multirow{6}{*}{ Medium } \\
\hline 5 & Biomedical Engineering & 1 & 5 & \\
\hline 6 & Industrial Engineering and Management & 1 & 5 & \\
\hline 7 & Mechanical Engineering & 1 & 5 & \\
\hline 8 & Textile Engineering & 1 & 5 & \\
\hline 9 & Textile Engineering (after working hours) & 1 & 5 & \\
\hline 10 & Telecommunications and Informatics Engineering & 0 & 0 & \multirow{6}{*}{ Weakest } \\
\hline 11 & Physics Engineering & 0 & 0 & \\
\hline 12 & Engineering and Management of Information Systems & 0 & 0 & \\
\hline 13 & Engineering and Management of Information Systems (after working hours) & 0 & 0 & \\
\hline 14 & Informatics Engineering & 0 & 0 & \\
\hline 15 & Industrial Electronics and Computers Engineering & 0 & 0 & \\
\hline
\end{tabular}


nothing is said if it is really Project-Based Learning (PBL), a methodology that opens the possibility of a work more oriented towards sustainability, although, depending on the theme or focus of the project. Investigating the information of the disciplines, it was provided only general information and in the item "teaching type" only informed if it requires student presence or not (e.g. distance learning course). However, there are some exceptions that will be described in the Master Integrated respective section.

\subsubsection{Integrated Master with strongest focus}

As identified in Table 2, 20\% of the programs were considered with the strongest focus in sustainability. The strongest is the Civil Engineering with 30\% (90 in 300 ECTS) of its ECTS with such focus. Civil Engineering is very akin with sustainability themes and topics. This program is organized into eight semesters of common core. In these semesters, nothing is in terms of environmental issues was found. The following two semesters are for training in four specific branches. In these four branches the structure of the two semesters is: in the first two compulsory courses, three electives of the specific area and an optional area of any University, and the second half of the final project. The branches are four: 1) Construction, 2) Hydraulics and Environment; 3) Planning and Transport Infrastructures and 4) Structures and Geotechnics.

The profiles of Structures and Geotechnics and Planning and Transport Infrastructures do not present courses related to sustainability. However, the profiles of Construction and Hydraulics and Environment have compulsory courses focused on this theme: Sustainable Construction (5 ECTS) and Quality, Safety and Environmental Management (5ECTS) and Water and Wastewater Treatment Processes (5 ECTS) and Water Management (5 ECTS), respectively.

It can be noted that these two profiles can be almost entirely focused on the area of sustainability if the student opts for courses with this approach. Also, by the number of optional courses, there would be the possibility of having a focus on issues environmental, however, it is important to note that none of this approach is worked in previous semesters. Among the courses, optional or not, that students can choose, there is the possibility of working on environmental issues, at least, in 14 courses such as Environmental lmpact Assessment (6 ECTS), Design and Operation of Treatment Plants (5 ECTS) or Green Buildings (5 ECTS). It is important to notice that the number of optional courses are only four.

According to the description of the Biological Engineering program, the students are "[...] The graduates will be competent professionals able to collaborate with the cleanup and quality control sectors of these industries [...]". This program is, by its nature, environmental focus. In the $7^{\text {th }}$ semester the program is divided into two branches: Chemical and Food Technology and Environmental Technology. The branch of Environmental Technology presents six courses specific to the area in the $7^{\text {th }}$ and $8^{\text {th }}$ semester and obviously focused on the sustainability:

- Elements on Environmental Engineering (5 ECTS)

- Laboratories of Environmental Technology (10 ECTS)

- Treatment of Water and Liquid Effluents (5 ECTS)

- Air Pollution (5 ECTS)

- Environmental Management (5 ECTS)

- Solid Waste Treatment (5 ECTS)

Chemical and Food Technology branch does not seem to have sustainability compulsory courses. The $9^{\text {th }}$ semester includes four optional sets with a different offer in terms of courses that varies according the branch. Some courses are related to sustainability:

- Modelling of Environmental Systems (5 ECTS)

- Molecular Biotechnology (5 ECTS)

- Energy and Environmental (5 ECTS)

- Oenology (5 ECTS)

- Clean Product and processes (5 ECTS)

- Environmental Technologies (5 ECTS) 
Materials Engineering program has three elective courses suitable for introduce sustainability issues: Composite materials (5 ECTS), Solid Wastes Treatment (5 ECTS) and Metallic Recycling (5 ECTS). Compulsory courses has Materials and Environment (5 ECTS), that involve sustainability topics and Materials Degradation (5 ECTS), that could involve sustainability topics.

In all cases, it is important to notice that some of the courses are naturally related with the environment, but not necessarily have their focus in sustainability. At the same time, others are not so related with sustainability but could be worked with this focus. This strongly depends on the teacher or on the learning methodology adopted.

\subsubsection{Integrated Master with medium focus}

In this category, it was introduced Polymer Engineering, Biomedical Engineering, Industrial Engineering and Management, Mechanical Engineering, Textile Engineering (and after work). This represents 33\% of the Integrated Masters offered by this university.

Polymer Engineering has a course named "Integradora", in English means Integrative, in the first seven semesters. In the $8^{\text {th }}$ semester it has two compulsory courses that involve environmental thematic: 1) Natural and Biodegradable Polymers (5 ECTS) and 2) Management and Environment in Plastic Industry (5 ECTS). In the rest of the courses, nothing was observed that indicates orientation for environmental issues.

Biomedical Engineering is organized like the others Integrated Masters. In the last two years $\left(4^{\text {th }}\right.$ and $\left.5^{\text {th }}\right)$ only one elective course includes environmental issues: Solid Wastes Treatment and Hospital Effluents (5 ECTS).

The Industrial Engineering and Management (IEM) program also presented just one elective course designated as Eco-Sustainable Production. Others could be orientated to sustainability issues but it depends on the teacher. Additionally, IEM has a type of course that gives flexibility to do whatever the coordinator of this course wants. This type of course is Integrated Project that is suitable to do this. IEM program has three Integrated Projects: Integrated Project of Industrial Engineering and Management 1 (IPIEMI - $1^{\text {st }}$ year, $1^{\text {st }}$ semester) and Integrated Project of Industrial Engineering and Management 11 and 111 (IPIEMII: $4^{\text {th }}$ year, $1^{\text {st }}$ semester and IPIEMIII $2^{\text {nd }}$ semester) described in Alves \& Leão (2015). These IPIEM projects involves all courses of the semester where it is developed.

Particularly, in the first semester of the first year, the project developed by the teams of students always approach sustainability issues (Moreira et al., 2011). Under the context of Project-Based Learning (PBL) the IEM students have been developing a sustainable product (e.g. bio alcohol, solar cooker, etc.) and the production system to produce this, where the students could develop sustainability competences (Colombo et al., 2014; Colombo et al., 2015a). The courses involved are Introduction to Industrial Engineering and Management, Calculus, Linear Algebra, Chemistry and Algorithms and Programming (all courses has 5 ECTS), involving a teacher's teamwork and effort from different Departments and Schools (Alves et al., 2015, 2016). These authors also believe, by doing this, they are in the right path to achieve DESD (Colombo et al., 2015b).

The Mechanical Engineering program includes an elective course called Energy and Environment that is focused in environmental thematic. This program also presents a course "Integradora", like Polymer Engineering, in the first eight semesters ( $1^{\text {st }}$ to $4^{\text {th }}$ year) that it serves for the students to develop a project. Nevertheless, by the description presented in the University website, this course did not integrate a project like the one developed in the IEM program, i.e., the project is developed inside this course not recurring to the others courses in the semester.

Textile Engineering has one course focused in environmental issues: Environmental Factors in Textile Industry (5 ECTS). It presents an interdisciplinary project from the $2^{\text {nd }}$ to $8^{\text {th }}$ semesters (Interdisciplinary Projects $1-\mathrm{VII}$ ) where the students had the opportunity to explore sustainability issues. Particularly, in the Interdisciplinary Project IV, the theme of the project is very specific: "Quality and environmental and energy sustainability in the design and development of a textile product: coveralls". None information is in the website about the teaching/ assessment methods.

\subsubsection{Integrated Masters with weakest focus}

Telecommunications and Informatics Engineering, Industrial Electronics and Computers Engineering, Engineering and Management of Information Systems (and after work hours), Physics Engineering do not present courses that indicates issues related with sustainability. This represents the remaining $40 \%$ of the courses. 


\subsection{Master degrees}

There are 27 master degrees (MSc.) offered in the website of the University. From these, with exception of Structural Analysis of Monuments and Historical Construction, with 60 ECTS, and Sustainable Built Environment with 90 ECTS, all programs have 120 ECTS. Table 3 presents the Master Programs and the number of courses for each related with sustainability.

The third question of the research cannot be answered with details, as in the case of Integrated Masters, because in the websites of the courses, there was no direct information on the approach and teaching/learning methodologies to work in sustainability or related, and the same happen by searching the specific information for courses. The exceptions are presented in the respective section of the program and course. In spite of the paper's authors did not identify integrated projects, according to the information available, these masters are organized in a theory, practice and experimentation combination in a context of learning oriented to project, defined by the Bologna process.

\subsubsection{Masters with strongest focus}

In this category are included three programs (11\%) of the master programs as the Table 3 shows. Sustainable Construction and Rehabilitation, as the name implies, has sustainability at its base, especially in the first of two specializations: Sustainable Building Conception and Management and Building Maintenance and Rehabilitation. In this program, 50\% of the ECTS are directly related to the theme of sustainability, with three compulsory subjects and one optional:

- Eco-efficient Construction Materials (5 ECTS)

- Ecology and Sustainability of Constructions (5ECTS)

- Energy and Comfort in Buildings (5 ECTS)

- Sustainable Structures Design (5 ECTS) (optional)

Table 3. Number of courses and ECTS related with sustainability in Master Degrees and their category.

\begin{tabular}{|c|c|c|c|c|}
\hline & Master in: & $\begin{array}{c}\text { Courses related } \\
\text { with sustainability }\end{array}$ & Number of ECTS & Category \\
\hline 1 & Environmental Management & 14 & 120 & \\
\hline 2 & Sustainable Built Environment & 13 & 90 & Strongest \\
\hline 3 & Sustainable Construction and Rehabilitation & 6 & 30 & \\
\hline 4 & Urban Engineering & 3 & 15 & \\
\hline 5 & Food Science and Technology & 2 & 16 & \\
\hline 6 & Engineering and Quality Management & 2 & 10 & \\
\hline 7 & Product Engineering & 1 & 5 & Medium \\
\hline 8 & Engineering Project Management & 1 & 5 & \\
\hline 9 & Systems Engineering & 1 & 5 & \\
\hline 10 & Textile Chemistry (After Working Hours) & 1 & 5 & \\
\hline 11 & Bioinformatics & 0 & 0 & \\
\hline 12 & Biotechnology & 0 & 0 & \\
\hline 13 & Design and Marketing & 0 & 0 & \\
\hline 14 & Engineering of Computer Networks and Telematics Services & 0 & 0 & \\
\hline 15 & Entrepreneurship in Technology and Information Services & 0 & 0 & \\
\hline 16 & Fashion Design and Communication & 0 & 0 & \\
\hline 17 & Human Engineering (After Working Hours) & 0 & 0 & \\
\hline 18 & Industrial Engineering & 0 & 0 & \\
\hline 19 & Informatics & 0 & 0 & Weakest \\
\hline 20 & Informatics Engineering & 0 & 0 & \\
\hline 21 & Information Systems & 0 & 0 & \\
\hline 22 & Mechatronics Engineering (After Working Hours) & 0 & 0 & \\
\hline 23 & Micro/Nano Technologies & 0 & 0 & \\
\hline 24 & Properties and Technology of Polymers & 0 & 0 & \\
\hline 25 & Structural Analysis of Monuments and Historical Construction (European Master's) & 0 & 0 & \\
\hline 26 & Structural Engineering & 0 & 0 & \\
\hline 27 & Technology and Digital Art & 0 & 0 & \\
\hline
\end{tabular}


The specialization Sustainable Building Conception and Management have two other compulsory courses: Efficient and Sustainable Building Design and Construction (5 ECTS); Sustainable Building Project Management (5 ECTS). According to the program information, this Master degree was organized in theoretical, practical and experimentation areas accordingly to Bologna orientations.

The Master on Environmental Management is oriented to problems' solution in process industries, as well as the acquisition of abilities, tools and soft skills in clean technologies and source pollution control that contribute to sustainable development. As expected, all courses involve the sustainability thematic:

- Clean Processes and Products (5 ECTS)

- Energy and Environment (5 ECTS)

- Environmental Law (5 ECTS)

- Environmental Management Systems (7,5 ECTS)

- Pollution Control Technologies 1 (7,5 ECTS)

- Economics and Environment (5 ECTS)

- Environmental Auditing (5 ECTS)

- Pollution Control Technologies II (5 ECTS)

- Recycling and Materials (5 ECTS)

- Strategies of Process Integration (7,5 ECTS)

- Dissertation (45 ECTS)

- Environment, Quality, and Safety (5 ECTS)

- Impact and Risk Studies (5 ECTS)

- Modelling of Environmental Systems (5 ECTS)

The Master (90 ECTS) in Sustainable Built Environment (iMiSBE) is developed by partnership among of universities and its objective is to promote a global movement in order to build an environment. As the name indicates, the focus of the program is sustainability and, as the previous, all courses have this focus, in spite of two (Building performance and Methods and Tools) do not have the word in the title. The courses are:

- Science of Sustainable Neighborhoods (5 ECTS)

- Building Performance (5 ECTS)

- Materials, Products and Systems for Sustainable Construction (5 ECTS)

- Sustainable Building Overview (5 ECTS)

- Environmental Principles (5 ECTS)

- Social and Economic Sustainability

- Sustainable Urban Performance (5 ECTS)

- Methods and Tools (5 ECTS)

- Integrated Design Process (5 ECTS)

- Integrated Research Project (5 ECTS)

- Integrated Urban Project (5 ECTS)

- Sustainable Rehabilitation of Buildings (5 ECTS)

- Dissertation on Sustainability Built Environment (5 ECTS)

It is important to refer that in this master and in the previous, the master thesis have the sustainability focus. An important aspect is that in some cases there a higher number of courses with an approach of sustainability than the ones that the students should frequent (i.e. that are compulsory). 


\subsubsection{Masters with medium focus}

In this category were included 26\% of the master degrees, namely the ones presented in the Table 3.

The Master in Systems Engineering aims to promote the study of complex and large scale systems. Curricular units are organized in four coherent topics: Logistics, Industrial Informatics, Decision Technologies and Quality. Some work areas where the professionals of this master could develop their activity are Manufacturing and services companies, public and private health services, consultancy, transportation systems, retailing, banks, financial and insurance, telecommunications, energy systems, among others. From these kind of activity it is evident that an approach of sustainability would be important for these professionals.

Nevertheless, what was founded was a course Lean Production Systems (5ECTS/120ECTS) which according the teacher could be worked to integrate sustainability concepts. This master offers a course of integrated project and two integrated projects in the Logistic option.

The master in Engineering of Product includes eco-design and eco-efficiency courses that focused in sustainability. It is expected that this focus is maintained in all courses of the master attending to the development and innovation that imbed.

The Master in Engineering and Quality Management puts emphasis on engineering techniques and management applied in planning, control of process and in the design and improvement of products and services. In this master it was found an optional course directly related with sustainability "Sustainability and Social Responsibility" (5ECTS/120ECTS) and a compulsory course called "Lean Six-Sigma" with some possibilities to integrate sustainability. Nevertheless, the paper authors consider that this master could have a greater approach to sustainability attending to association of this theme with quality.

The MSc in Urban Engineering presents a multidisciplinary approach focused on the following domains: urban planning, hydraulic and environmental structures, road infrastructures and urban geotechnics. In spite of indicating a need of an integrated approach to the urban problems solutions, did not present integrated projects. The courses focused on sustainability are three: Sustainable Mobility, Sustainable Urban Drainage and Urban Environmental Management (15 ECTS/120ECTS). Some courses deal with environmental resources such as Water treatment, Water Resources Management, however the focus could be or not of sustainability. But it is important to notice that in the master presentation it is focused the knowledge and competences development for sustainable management of cities.

The Master's in Engineering Project Management (MGPE) aims to train professionals of various profiles, prepared to manage technology development and implementation processes of highly complex engineering projects. The training endeavored by MGPE enables specialization into three engineering project areas: construction (building and civil engineering works), industrial engineering (manufacturing industry and services) and information systems (information technology and information systems). It is observes that in the master presentation there is not a sustainability approach, only economical and of quality. Only one course refers environment: Quality, Environment and Safety Management (5ECTS/120ECTS).

According to the presentation of the program, the "Textile Chemistry" covers areas of the textile sector that account for the highest added value: dyeing, printing and finishing. It also includes the related sector of chemical fiber production, as well as all aspects related to protection of the environment, essential for the European textile industry. Only one course "Environmental Factors in Textile Industry" (5ECTS/120ECTS) shows the environmental approach. There is a possibility for this Master to approach sustainability because the curriculum of the program's course is designed according to the teaching-learning approach, characterized by stimulate learning by placing students with real problems (problem-based learning) and is part of a strategy to offer multidisciplinary postgraduate training.

Though the master presentation of Technology and Food Science did not presented an approach of sustainability, it was found a higher number of courses with this focus than in others programs. They are: Environmental Technologies, Quality and Environment Management Systems Certification, Organic Farming (16ECTS/120ECTS).

\subsubsection{Master with weakest focus}

In this category, it were included 17 programs, i.e., 63\% of the total master degrees that do not present any course related with sustainability (Table 3 above). It is evident that some programs do not facilitate the theme integration but there are others that is expected a clearer approach to sustainability but, by the contrary, do not work at all the theme. The integrated projects that could allow a systemic approach to sustainability was just identified in five programs of this degree. 


\subsection{Doctoral programs}

The School of Engineering offers 24 doctoral programs from which 11 with 240 ECTS, 12 with 180 ECTS and one with 210 ECTS. Table 4 presents the PhD program and the number of courses and ECTS for each PhD related with sustainability. It is important to notice that most courses in these programs are optional.

Regarding the third research question, in doctoral programs, as in master and integrated master, there is no specific information on teaching/learning methodologies of the courses and, consequently, to work sustainability or related topics. The exceptions are presented together with the presentation of each program in the respective section.

\subsubsection{PhD with strongest focus}

Only $12,5 \%$ of the PhD programs were classified as strongest. From the 30\% of the PhD that presented an approach to sustainability, the program Sustainable Built Environment was considered the strongest because it offers a great number of courses with this focus such as Eco-efficient Construction Materials; Ecology and Sustainable of Construction; Urban Environmental Management; Life Cycle Assessment of Building Elements; Neighborhood Sustainability Performance; Outdoor Environment; Social and Economic Sustainability; Sustainable Retrofit of Buildings.

In this category was also considered the Mechanical and Civil Engineering. The Mechanical Engineering PhD (240 ECTS) presents, from the seven optional courses, four focused in environmental issues that are:

1. Renewable Energies (5 ECTS),

2. Environmental Protection Technologies (5 ECTS),

3. Waste Treatment and Metal Recycling (5 ECTS)

4. Energy Management and Conversion (5 ECTS).

The Civil Engineering PhD (180 ECTS) is stronger than the previous in approaching the sustainability. From the four optional courses Scientific-Technological and the two Behavioral and of Innovation, there are some related with sustainability:

Table 4. Number of courses and ECTS related with sustainability in PhD degrees and their category.

\begin{tabular}{llccc}
\hline \multicolumn{1}{c}{ Doctoral Program in: } & Courses related with sustainability & Number of ECTS & Category \\
\hline 1 & Sustainable Built Environment & 24 & 120 & Strongest \\
2 & Mechanical Engineering & 6 & 30 & 20 \\
3 & Civil Engineering & 4 & 10 & 10 \\
\hline 4 & Advanced Materials and Processing & 2 & 5 & Medium \\
5 & Solid Waste Management and Treatment & 1 & 5 & 0 \\
6 & Industrial and Systems Engineering & 1 & 0 \\
7 & Textile Engineering & 0 & 0 \\
\hline 8 & Advanced Engineering Systems for lndustry & 0 & 0 \\
9 & Bioengineering & 0 & 0 \\
10 & Biomedical Engineering & 0 & 0 \\
11 & Chemical and Biological Engineering & 0 & 0 \\
12 & Electronics and Computer Engineering & 0 & 0 \\
13 & Fashion Design & 0 & 0 \\
14 & Food Science and Technology and Nutrition & 0 & 0 \\
15 & Informatics & 0 & 0 \\
16 & Informatics MAP-i (PDI) & 0 & 0 \\
17 & Information System and Technology & 0 & 0 \\
18 & Leaders for Technical Industries (PDI) & 0 & 0 \\
19 & Marine Biotechnology and Aquaculture & 0 & 0 \\
20 & Materials Engineering & 0 & 0 \\
21 & Optimization of Industrial Systems and Services & 0 & 0 \\
22 & Science and Engineering of Polymers and Composites & 0 & 0 \\
23 & Telecommunications MAP-tele (PDI) & 0 & 0 \\
24 & Tissue Regenerative Medicine and Stem Cells & & 0 \\
\hline & & 0 & 0 \\
\end{tabular}


1. Sustainable Construction: Principles and Practices (5 ECTS)

2. Development, Conception and Assessment of Sustainable (5 ECTS)

3. Eco-efficiency in Buildings (5 ECTS)

4. Sustainable Management of Groundwater (5 ECTS)

There are others with good possibilities to integrate environmental approaches, such as: Water Quality and Public Health (5 ECTS), Rehabilitation of Constructions (5 ECTS) and Intelligent Cities (5 ECTS). It is important to notice that there are many courses that according to the objectives of the course or the teacher could easily integrate sustainability concepts.

\subsubsection{PhD with medium focus}

In this category was included four PhD programs (17\%). Some are very similar to the PhD included in the previous category. The PhD of Industrial and Systems Engineering (180 ECTS) offers 96 courses but a few are related with sustainability or work sustainability. From these courses PhD student should frequent mandatorily two, none related with sustainability and all the others are optional. It was identified eight optional courses that could have an approach to sustainability depending on the themes and the approach worked by the teacher. These includes Economy and Environment (5 ECTS) more related to the sustainability and others could offer this possibility such as Lean Project Management, Lean Flow Management, Lean Production Systems and Integrated Management of Projects.

The Textile Engineering PhD (180 ECTS) presents only an optional course focus in environmental theme that it is Environmental Factors in Textile Industry. Nevertheless, in a high number of courses it was identified the possibility of sustainability approach.

Although expected an environmental focus, the Water and treatment of residues PhD (180 ECTS) could not be identified as a strongest in sustainability because, beyond offering a few courses, are only two the courses in the sustainability theme: Solid Waste Management and Treatment (5 ECTS) and Recycling and Materials (5 ECTS).

In the PhD of Advanced Materials and Processing it was identified the optional course Waste Recycling and Valorization (4,5 ECTS) related with sustainability and the compulsory course Material Degradation and Protection (6 ECTS) that indicates an approach to sustainability.

\subsubsection{PhD with weakest focus}

From the PhD offered, 16 (70\%) did not present courses that indicate a clear approach to environmental issues. Although, some presents strong possibilities for such, some in a great number of courses and others in a few such is the case of the courses Management of Innovation and Project Management presented in a high number of programs. It is important to notice that for some programs it was expected a strong approach such as Bioengineering and Biological and Chemistry Engineering but this do not happen.

\subsection{Discussion}

From the above it is possible to provide a summary of the number of programs in each category by degree. This summary is represented in the graph of the Figure 1. Only three programs in each degree were classified as strongest, being the IMSc the degree with higher percentage of programs that approach sustainability.

It can be observed that some programs are naturally related with sustainability as the programs classified as "Strongest" above. Nevertheless, in a program of 300 ECTS, only a small part is dedicated to sustainability issues even in the Civil Engineering program, the strongest one (just 30\% of ECTS are related with this). Based only in the information provided in the university website, it seems that many programs and courses remain without addressing this topic (Figure 2), in spite of having the potential to work sustainability issues. For the IMSc just, approximately, $6 \%$ are related to sustainability.

There are others (e.g. classified here as "Medium" and "Weakest") that are not so directly related or indicate sustainability approach but they have been worked to include this, orienting the teaching to this focus. This depends on the teacher and pedagogical approach adopted for the course. For instance, developing projects in the courses and, more important, in a context of a learning methodology like PBL (IEM projects) it seems a better way to engage students in sustainability cause, as referred in the literature review. 


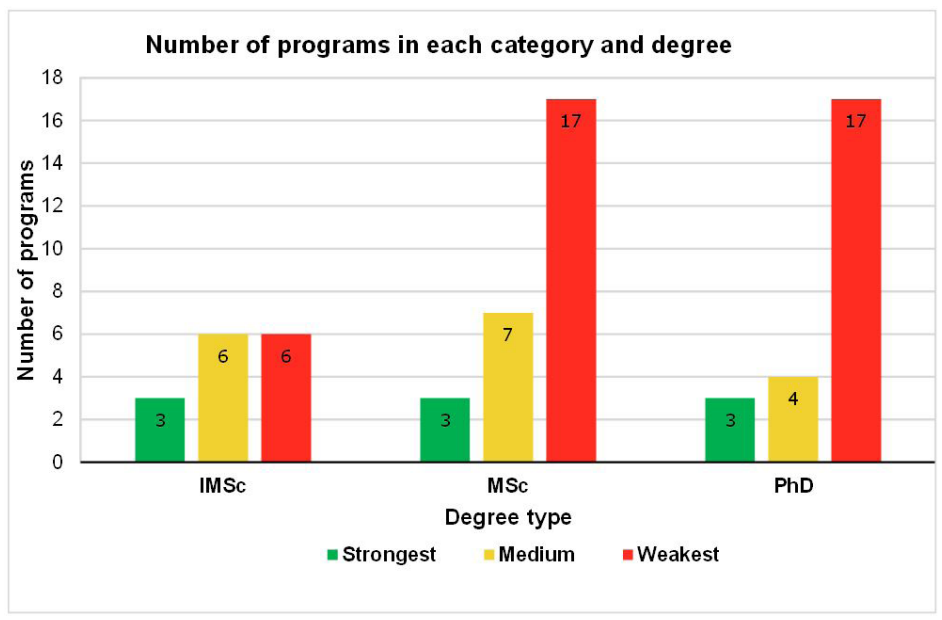

Figure 1. Number of programs in each category by degree type.

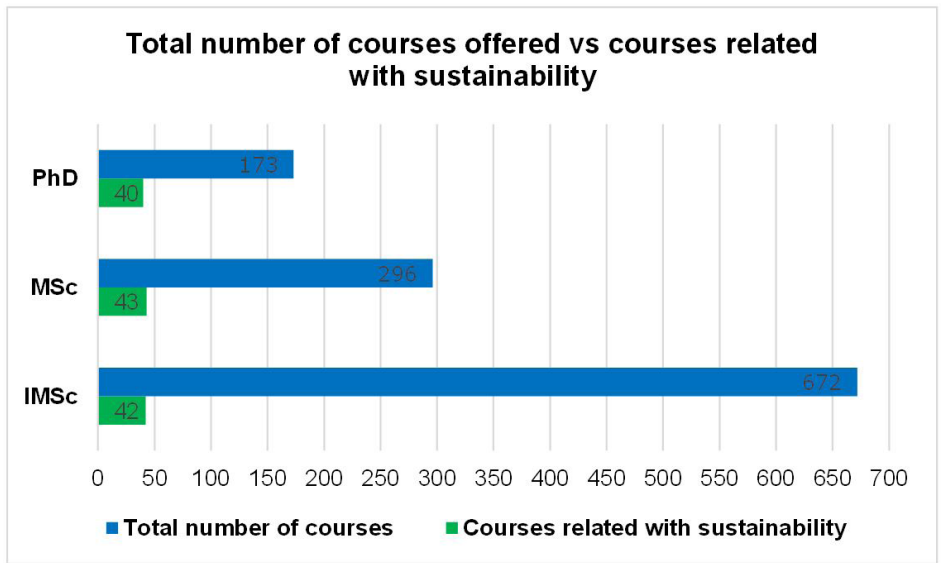

Figure 2. Total number of courses offered vs courses related with sustainability.

A consult to the various courses details (e.g. teaching and assessment methods described in the course information) reveals that learning methodologies and methods are mainly based on traditional methods such expositive classes, groups work, case studies, discussion in the classes, assignments, tests, among others. The exceptions were referred in the respective program and/or course. Some courses also referred the use of simulation informatics tools and visits to laboratories. Laboratory courses are the courses that, by their nature, engage students in practical activities. All programs that includes Interdisciplinary Projects or "Integradoras" refer the project based teaching but none (except IPIEM courses) referred the specific learning methodology used.

Even worked with a methodology as the PBL, as already discussed, effective assumption of sustainability in professional practice will only occur if this is a theme worked throughout the program. This requires that all those responsible for the training of future professionals, teachers, must have incorporated this issue at the core of each of the disciplines.

The programs and courses presented here that integrate sustainability are a small sample of what has been done in university. Nevertheless, as already referred in the research methodology section, the documentary analysis as a research method is very limited because much more could be in progress. As the literature reviewed showed (Dahms et al., 2013; Hansen et al., 2014a) it is necessary more research methods to better study this theme, e.g. interviews.

Additionally, others aspects must be improved to increase awareness of sustainability concept. This should start by training the trainers (teachers) and this requires a transformation work, part of a larger meaning (Colombo, 2004). As stated by Morin \& Le Moigne (2000) the true reform (of education systems) will only 
happen when an awareness of the problems is realized. Of course, each individual must seek, individually and collectively, to open and contribute to the development of critical thinking.

It is understood that this training provides an opportunity to transform both in terms of course content and methodology. Create teacher training programs can be a big step for the effective integration of sustainability in engineering education (European Commission, 2013). This formation offers the means and methods to effect change, involving the paradigmatic and epistemological questions (worldview) and pedagogical (teaching- learning methods). Such methodologies and methods should include a learning process similar to the one founded in professional future of graduates, namely, practical activities, hands-on approaches, projects among others. This means a model that it is interdisciplinary, and not divided in courses, based on a strong philosophy that promote content but also competence mastery (Flumerfelt et al., 2014, 2015; Alves et al., 2014; Colombo, 2004).

Additionally, a lot of questions continue without an answer, for example, the ones related with the performance measures to consider to evaluate sustainability competencies; the contents to integrate; the learning/teaching methodologies; the training of teachers to teach sustainability, among others.

\section{Conclusion}

The objective of this paper was to analyze the engineering programs and courses of a Portuguese Public university on the point of view of sustainability integration. This university has some initiatives to greening the campus reported in the sustainability report. Also, many research centers are dedicated to this theme. Additionally, some programs are also worked to introduce this thematic.

Some of these are engineering programs that are more or less related with sustainability theme. According to the number of courses named-related with sustainability, the programs of Integrated Master were classified as "Strongest" (three were identified in this category that corresponds to $20 \%$ of the programs), Medium (six programs, $40 \%$ ) and "Weakest" (six belongs to this group, the remaining 40\%). The Master programs ( $2^{\text {nd }}$ cycle), three of them were considered "Strongest" (11\%), seven are "Medium" (26\%) and 17 "Weakest" (63\%). Among doctoral programs three of them are considered "Strongest" category (13\%), four are considered Medium (17\%) and 17 programs does not have any sustainability approach being inserted in the "Weakest" category (71\%).

The sustainability theme is integrated in most courses using traditional approach instead of active methodologies, such as PBL active learning methodologies. PBL was inserted in IEM projects but sustainability is worked only in the first year. With a different approach, some engineering departments indorse research and support communities' centers such as Wastes Valorization Centre that promote conferences in areas related with sustainability. An immense potential exist in many programs and courses to work sustainability issues attending to the reduced percentages of courses related with sustainability when compared with total number of courses offered (6\% IMSc.; 15\% MSc. and 23\% PhD). This paper makes a contribution to remember the need to increase efforts in integrating sustainability in university degrees in order to greening the campus of university and educate for sustainable development.

By being limited to the information retrieved from the published study plans in the official website, the paper authors considered this a preliminary study. As other studies, namely the above referred, there are many programs that do not incorporate sustainability and a lot has to be made to promote this in the courses. So, this kind of study is necessary to increase the knowledge about efforts to pursuit education for sustainable development. As a future work and to know better the sustainability integration through PBL in the engineering courses of this university, a deeper study needs to be undertaken by using other research methods such as, for example, interviews with teachers.

\section{Acknowledgements}

This work has been supported by COMPETE: P0Cl-01-0145-FEDER-007043 and FCT - Fundação para a Ciência e Tecnologia within the Project Scope: UID/CEC/00319/2013.

\section{References}

Allen, D., Allenby, B., Bridges, M., Crittenden, J., Davidson, C., Hendrickson, C., Matthews, S., Murphy, C., \& Pijawka, D. (2008). Benchmarking Sustainability Engineering Education: Final Report (EPA Grant X3-83235101-0). Austin: CSE. Retrieved in 10 April 2014, from www.csengin.org

Alves, A. C., \& Leão, C. P. (2015). Action, practice and research in project-based learning in an industrial engineering and management program. In Proceedings of the ASME 2015 International Mechanical Engineering Congress \& Exposition (IMECE2O15). Houston, Texas, USA. http://doi:10.1115/IMECE2015-51438 
Alves, A. C., Kahlen, F. J., Flumerfelt, S., \& Siriban-Manalang, A. B. (2014). Fostering Sustainable Development thinking through lean engineering education. In Proceedings of the ASME International Mechanical Engineering Congress and Exposition. Montreal, Quebec, Canada. http://doi.org/10.1115/IMECE2014-38192.

Alves, A. C., Sousa, R. M., Fernandes, S., Cardoso, E., Carvalho, M. A., Figueiredo, J., \& Pereira, R. M. S. (2015). Teacher's experiences in PBL: implications for practice. European Journal of Engineering Education, 1-19. http://dx.doi.org/10.1080/03043797.2015.1023782.

Alves, A. C., Sousa, R. M., Moreira, F., Carvalho, M. A., Cardoso, E., Pimenta, P., Malheiro, M. T., Brito, 1., Fernandes, S., \& Mesquita, D. (2016). Managing PBL difficulties in an Industrial Engineering and Management program. Journal of Industrial Engineering and Management, 9(3), 73-89. http://dx.doi.org/10.3926/jiem.1816.

Bernaldo, M. O., Fernández, G., \& Hilliard, 1. 0. (2016). Contribution of universities to sustainable development. In Proceedings of the PAEE/ALE'2016, 8th International Symposium on Project Approaches in Engineering Education (PAEE); 14th Active Learning in Engineering Education Workshop (ALE). Guimarães, Portugal.

Colombo, C. R. (2004). Princípios teórico-práticos para formação de engenheiros civis: em perspetiva de uma construção civil voltada à sustentabilidade. Florianópolis: UFSC.

Colombo, C. R., \& Alves, A. C. (2016). Sustainability in Engineering Programs in UMinho. In Proceedings of the PAEE/ALE'2016, 8th International Symposium on Project Approaches in Engineering Education (PAEE) and 14th Active Learning in Engineering Education Workshop (ALE). Guimarães, Portugal.

Colombo, C. R., Alves, A. C., Van Hattum-Janssen, N., \& Moreira, F. (2014). Active learning based sustainability education: a case study. In Proceedings of the Project Approaches in Engineering Education (PAEE2014). Medellin, Colombia. Retrieved in 20 May 2017 , from http://repositorium.sdum.uminho.pt/bitstream/1822/30173/1/paee2014_submission_55.pdf

Colombo, C. R., Moreira, F., \& Alves, A. C. (2015a). Sustainability Education in PBL Education: the case study of IEM. In Proceedings of the Seventh International Symposium on Project Approaches in Engineering Education (PAEE'2015) and the International Joint Conference on the Learner in Engineering Education (IJCLEE'2015). Donostia, San Sebastian, Spain. Retrieved in 20 May 2017, from http://hdl.handle.net/1822/39124

Colombo, C. R., Alves, A. C., van Hattum-Janssen, N., \& Moreira, F. (2015b). A study on impact of the UN decade of education for sustainable development on industrial engineering education. Dirección Y Organización, 56, 4-9.

Cotton, D., Bailey, 1., Warren, M., \& Bissell, S. (2009). Revolutions and second-best solutions: education for sustainable development in higher education. Studies in Higher Education, 34(7), 719-733. http://dx.doi.org/10.1080/03075070802641552.

Dahms, M. L., Hansen, K. K., \& Otrel-Cass, K. (2013). Sustainability in Engineering Education - is PBL the answer? In Proceedings of the 41th SEFI Conference. Leuven, Belgium.

Daneikina, N. V., Daneykin, Y. V., \& Chuchalin, A. 1. (2016). Sustainability in three-cycle engineering education based on CDI0 syllabus. In Proceedings of the PAEE/ALE'2016, 8th International Symposium on Project Approaches in Engineering Education Education (PAEE); 14th Active Learning in Engineering Education Workshop (ALE). Guimarães, Portugal.

European Association of Institutions in Higher Education - EURASHE. (1999). The Bologna Declaration of 19 June 1999: joint declaration of the European Ministers of Education. Brussels: The European Higher Education Area.

European Commission - EC, \& Education, Audiovisual and Culture Executive Agency - EACEA. (2010). Eurydice: focus on higher education in Europe 2010: the impact of the bologna process. Brussels: Eurydice. http://dx.doi.org/10.2797/38158.

European Commission - EC. (2013). High level group on the modernisation of higher education: improving the quality of teaching and learning in Europe's higher education institutions (Report, 81 p.). Belgium: Luxembourg: Publications Office of the European Union.

Flumerfelt, S., Alves, A. C., \& Khalen, F.-J. (2014). Lean engineering education: the DNA of content and competency. In Proceedings of the 2014 IIE Engineering Lean and Six Sigma Conference Lean. Orlando, Florida, USA.

Flumerfelt, S., Kahlen, F.-J., Alves, A. C., \& Siriban-Manalang, A. B. (2015). Lean engineering education: driving content and competency mastery. New York: ASME Press.

Guerra, A., Holgaard, J., \& Kolmos, A. (2013). Project-organized learning and the development of competences in Engineering Education for Sustainable Development. In Proceedings of the European Roundtable on Sustainable Consumption and Production \& The Environmental Management for Sustainable Universities (ERSCP-EMSU). Denmark.

Hansen, K. K., Dahms, M. L., Otrel-Cass, K., \& Guerra, A. (2014a). Problem-based learning and sustainability - practice and potential. Denmark: Faculty of Engineering and Science, Aalborg University.

Hansen, K. K., Otrel-Cass, K., Guerra, A., \& Dahms, M. L. (2014b). Good examples catalogue. Denmark: Faculty of Engineering and Science, Aalborg University.

Holgaard, J. E., Hadgraft, R., Kolmos, A., \& Guerra, A. (2016). Strategies for education for sustainable development - Danish and Australian perspectives. Journal of Cleaner Production, 112, 3479-3491. http://dx.doi.org/10.1016/j.jclepro.2015.09.063.

Holmberg, J., Svanström, M., Peet, D.-J., Mulder, K., Ferrer-Balas, D., \& Segalàs, J. (2008). Embedding sustainability in higher education through interaction with lecturers: case studies from three European technical universities. European Journal of Engineering Education, 33(3), 271-282. http://dx.doi.org/10.1080/03043790802088491.

Junyent, M., \& Ciurana, A. M. G. (2008). Education for sustainability in university studies: a model for reorienting the curriculum. British Educational Research Journal, 34(6), 763-782. http://dx.doi.org/10.1080/01411920802041343.

Mello, J., Zinden, M. L., Santos, A. C., Rocha, C. H., Felix, J. C., Borges, S., \& Monteiro, S. (2016). Innovative experiences and proposals in engineering education for sustainability : application to the University of Brasilia undergraduate production engineering program. In Proceedings of the PAEE/ALE'2016, 8th International Symposium on Project Approaches in Engineering Education (PAEE); 14th Active Learning in Engineering Education Workshop (ALE). Guimarães, Portugal.

Moreira, F., Mesquita, D., \& van Hattum-Janssen, N. (2011). The importance of the project theme in Project-Based learning: a study of student and teacher perceptions. In Proceedings of the 2011 Project Approaches in Engineering Education (Vol. 53). Lisbon, Portugal. http://dx.doi.org/10.1017/CB09781107415324.004.

Morin, E., \& Le Moigne, J.-L. (2000). A inteligência da complexidade (Trad. N. M. Falci). São Paulo: Editora Peirópolis.

Ramísio, P. J. (Coord.). (2015). Relatório de sustentabilidade 2014. Braga, Portugal: Universidade do Minho. 
Ruscheinsky, A., Guerra, A. F. S., Figueiredo, M. L., Leme, P. C. S., Ranieri, V. E. L., \& Delitti, W. B. C. (2014). Ambientalização nas instituições de educação superior no Brasil: caminhos trilhados, desafios e possibilidades (Vol. 1). Cambridge: Universidade de São Paulo.

Sammalisto, K., \& Lindhqvist, T. (2008). Integration of sustainability in higher education: a study with international perspectives. Innovative Higher Education, 32(4), 221-233. http://dx.doi.org/10.1007/s10755-007-9052-x.

United Nations - UN. (2013). Proposal for a global action programme on Education for Sustainable Development as follow-up to the United Nations Decade of Education for Sustainable Development (DESD) after 2014. In Proceedings of the General Conference 37th Session, Paris, 2013. Paris. Retrieved in 13 March 2016, from http://unesdoc.unesco.org/images/0022/002243/224368e.pdf

United Nations - UN. (2016a). Goal 4 - ensure inclusive and equitable quality education and promote lifelong learning opportunities for all. Sustainable development knowledge platform. Retrieved in 26 August 2016, from https://sustainabledevelopment.un.org/ topics/education

United Nations - UN. (2016b). Higher education sustainability initiative. sustainable development knowledge platform. Retrieved in 26 August 2016, from https://sustainabledevelopment.un.org/sdinaction/hesi

United Nations Educational, Scientific and Cultural Organization - UNESCO. (2005). United Nations decade of education for sustainable development 2005-2014 draft international implementation scheme (Vol. 1). Paris: UNESCO.

United Nations Educational, Scientific and Cultural Organization - UNESCO. (2014). Shaping the future we want: UN decade of education for sustainable development (2005-2014) (Final Report). Paris: UNESCO. Retrieved in 13 March 2016, from http://unesdoc.unesco. org/images/0023/002301/230171e.pdf

Wigmore, A., \& Ruiz, M. (2010). Sustainability assessment in higher education institutions - the STARS system. Ramon Llull Journal of Applied Ethics, 25-42.

Received: Sept. 9, 2016

Accepted: May 9, 2017 